\title{
Destruction HIV viral RNA by siDNA triggering RNAse $\mathrm{H}$
}

\author{
Karin Moelling \\ From $16^{\text {th }}$ International Symposium on HIV and Emerging Infectious Diseases \\ Marseille, France. 24-26 March 2010
}

\section{Background}

We are developing an alternative approach to siRNA, which may be designated as siDNA, small interfering DNA, by using hairpin-loop-structured DNA oligodeoxynucleotides (ODN), targeted to viral or cellular mRNAs. ODNs activate the viral RNase $\mathrm{H}$ in retroviral particles and cellular RNases $\mathrm{H}$ inside the cell. Also Ago 2 may play a role. Other inhibitory mechanisms such as translational arrest may contribute.

\section{Methods}

We selected ODNs against various viral and mRNAs of HIV, HSV, Influenza, HCV, HBV, and the terminal repeat of telomerases in malignant melanomas in mice. The ODNs were applied with or without carriers. Furthermore their effects were directly compared to those of single-stranded antisense DNAs and siRNAs to allow comparison of the various efficiencies.

\section{Results}

The ODNs were most effective in HIV. We are able to induce HIV suicide and inactivate HIV virus particles to prevent infections, inactivate cell-free HIV in the blood from infected individuals, in the vagina of mice, and increase survival time of retroviral-infected mice. Also influenza virus replication was reduced in the lungs of a mouse model. Furthermore we could reduce malignant melanoma-formation tumor formation in mice targeting the telomerase. The effects are sequence- and dose dependent, but the optimal algorithm is not yet known. We are analyzing whether there is a preference for $G$ tracts, which may form higher-ordered structures and enhance uptake

Correspondence: moelling@imm.uzh.ch

University of Zurich, Zurich, Switzerland

๑ 2010 Moelling; licensee BioMed Central Ltd

\section{Discussion}

The dsODNS are often superior to single-stranded antisense DNA and resemble the effects of siRNAs but with different kinetics. The method may complement existing silencing approaches.

Published: 11 May 2010

doi:10.1186/1742-4690-7-S1-P95

Cite this article as: Moelling: Destruction HIV viral RNA by siDNA

triggering RNAse H. Retrovirology 2010 7(Suppl 1):P95.
Submit your next manuscript to BioMed Central and take full advantage of:

- Convenient online submission

- Thorough peer review

- No space constraints or color figure charges

- Immediate publication on acceptance

- Inclusion in PubMed, CAS, Scopus and Google Scholar

- Research which is freely available for redistribution

Submit your manuscript at www.biomedcentral.com/submit
C Biomed Central 